Technical Report 1089

\title{
Virtual Environments for Dismounted Soldier Training and Performance: Results, Recommendations, and Issues
}

\author{
Bruce W. Knerr, Donald R. Lampton, Michael J. Singer, \\ Bob G. Witmer, and Stephen L. Goldberg \\ U.S. Army Research Institute \\ Kimberly J. Parsons and James Parsons \\ Institute for Simulation and Training
}

Simulator Systems Research Unit

Stephen L. Goldberg, Chief

U.S. Army Research Institute for the Behavioral and Social Sciences 5001 Eisenhower Avenue, Alexandria, Virginia 22333-5600

November 1998 